\title{
OVERLAP BETWEEN PERSONAL AND GROUP IDENTITY AND ITS RELATION WITH RADICAL PRO-GROUP ATTITUDES: DATA FROM A CENTRAL EUROPEAN CULTURAL CONTEXT
}

\author{
Tomasz BESTA \\ University of Gdansk \\ ul. Bażyńskiego 4, 80-952 Gdańsk, Poland \\ E-mail: t.besta@ug.edu.pl
}

\begin{abstract}
Previous research demonstrated that group adherence, which manifests itself by personal and social identity fusion, is related to radical pro-group attitudes and that this relationship is stronger for measures of identity fusion than group identification. A series of four studies (total $\mathrm{n}=872$ ) explored whether in different cultural conditions (i.e., in Central Europe) identity fusion is related to attitudes of fighting in order to protect one's own group and whether that influences the declared tendency to self-sacrifice. Moreover, to extend previous results, the current study tested if fusion is related to sense of control, social approval and self-concept clarity. The results indicate that identity fusion (as measured on a pictorial scale) is linked to radical behaviors operationalized in various ways and to the feeling of self-certainty.
\end{abstract}

Key words: identity fusion, radicalization of attitudes, group identification, social identity

\section{OVERVIEW}

To date, most analyses of relationships between group processes and radical behaviors have been guided by either the realistic conflict theory or social identity theory (SIT) and the self-categorization theory (SCT) (Sherif et al., 1961; Tajfel, Turner, 1979). Recently, a number of studies were conducted to verify a new theoretical framework, namely the identity fusion theory (Seyle, 2007; Swann, Jr. et al., 2010a; Swann, Jr.. et al., 2010b; Swann, Jr. et al., 2012). Identity fusion is defined as the overlap between personal and social self. The authors of the identity fusion theory, building on research on selfverification motivation (Swann, Jr., Stein-
Seroussi, Giesler, 1992) and debating the theory of social identification (Turner et al., 1987), argue that a strong sense of group adherence does not have to be related to a sense of depersonalization and loss of individual identity. Although identity fusion is associated with SIT, the authors of this concept point out major differences between the two. Identify fusion is described as a state in which the boundaries between the self and the group become blurred, or as a "feeling of oneness with the group that induces people to tether their feelings of personal agency to the group" (Swann et al., 2010a) and group identification represents an explicit awareness that the group is important to the person, it is a part of his or her identity. The most highlighted difference between those

DOI: $10.21909 /$ sp.2014.01.651 
two constructs is related to the exclusiveness of the social identity. Whereas SIT stresses the principle of functional antagonism (Turner et al., 1987), that is, a presumption that the salience of one identity (e.g., group) diminishes the salience of other identity (e.g., personal), identity fusion theory proposes that personal and social identities could be simultaneously active. In other words, a person who is strongly fused with the group could retain both a strong sense of personal and group identity (Swann, Jr. et al., 2009). Moreover, identity fusion is a state that predisposed people to take radical action on behalf of the group, not merely to follow the leaders' directions.

Studies conducted support those claims. For example, when it comes to fused persons, activation of personal identity had the same effect on their attitudes as activation of social identity. That is, the personal identity of fused people is functionally equivalent to their groups' identities (Swann et al., 2009). Strong association between fusion and radical attitudes has been confirmed (Gómez et al., 2011), as has the role of self-verification strivings: fused individuals were especially prone to express radical pro-group opinions and fight on behalf of their fellow group members when their self-schema has been challenged (Swann et al., 2009). Furthermore, an elevated feeling of agency (i.e., by physical activities) results in the endorsement of pro-group activities among fused persons (Swann et al., 2010b).

However, most of this research was conducted in two countries, Spain or the United States. Taking into consideration the postulate of conducting psychology studies beyond samples consisting of Western countries' students (Henrich, Heine, Norenzayan, 2010), the main goal of the current studies was to validate in a Central European cultural context the results obtained in the previous research.

\section{CURRENT STUDIES}

The presented studies examine the relationship between identity fusion, willingness to fight for one's own group and declarative self-sacrifice for other group members. Testing to determine if the results from Spain and the USA are similar to those in the Polish context seems particularly interesting, as Poland is a country with low social trust and a prevalent pessimistic life outlook (Dolinski, 1996). Moreover, the common tendency to justify the status quo and existing social system that is visible in many nations (Jost, Banaji, Nosek, 2004) is low in Poland, where the system itself is seen as unjust and harmful (Wojciszke, 2004; Wojciszke, 2006). Additionally, the current studies extend previous research and examine whether identity fusion is related to a sense of control, social approval and self-concept clarity. As for the locus of control, if group fusion does not cause a decrease in personal identity's importance and if, at the same time, it is related to an increase in pro-group attitudes, then fused persons should display a higher internal locus of control. However, if identity fusion is connected to depersonalization and loss of personal identity, then fused individuals should turn to their group for guidance on how to act and what to think, and the external locus of control should prevail. The current studies also examine whether identity fusion is related to a greater need for social approval, which in turn could influence the willingness to give more pro-group responses. If fused people were prone to socially acceptable declarations, this would 
be an important limitation of previously obtained results. As for self-certainty, the studies explore whether identity fusion is related to self-concept clarity, defined as a confidence in one's own traits and attitudes. One could argue that if identity fusion is the result of an overlap between personal self and social identity, then fused individuals should also display higher self-concept clarity, because their self-schemas are more vivid and they know better who they are and what their values and characteristics are. Fused people do not have to choose between conflicting dimensions of social and personal self. On the other hand, it could be assumed that identity fusion is not related to self-concept clarity, as fusion of personal agency and a group schema can designate clear and certain group stereotypes and traits as well as those less well-defined and more vague. Thus, this issue seems to be important and worth exploring in order to test the construct's validation.

The first study tested whether identity fusion is related to the willingness to fight and self-sacrifice for fellow Poles. The second study tested whether fusion is related to passive nationalism and to self-concept clarity. Studies three and four tested whether fusion was also connected to greater inclination for self-sacrifice, demonstrated in answers to a modified version of the trolley problem (in earlier research by Swann et al., 2010b). Studies three and four addressed the relationship between identity fusion and locus of control. In order to examine the relationship between fusion and sensitivity to other's opinions, study four also included a social approval scale.

\section{PRELIMINARYANALYSES}

Identity fusion was operationalized and measured accordingly to the theory presented by identity fusion researchers (Swann et al., 2009) and is based on previous studies on relationships strength (Aron, Aron, Smollan, 1992). The measurement itself, as in the previous research, was based on a simple wordless scale on which the participants were to mark what their relationships with the group were (i.e., with Poland). Option A designated total independence of self from the group while option E signified complete overlap of the self-concept and the group (see Figure 1).

Preliminary data analysis showed that, as with research in the U.S. (Seyle, 2007), it will be most appropriate to distinguish a group of fused people in a way that includes people who classified themselves as belonging to either the D or E sub-groups. Although the more conservative approach to identity fusion suggests treating only the E sub-group,

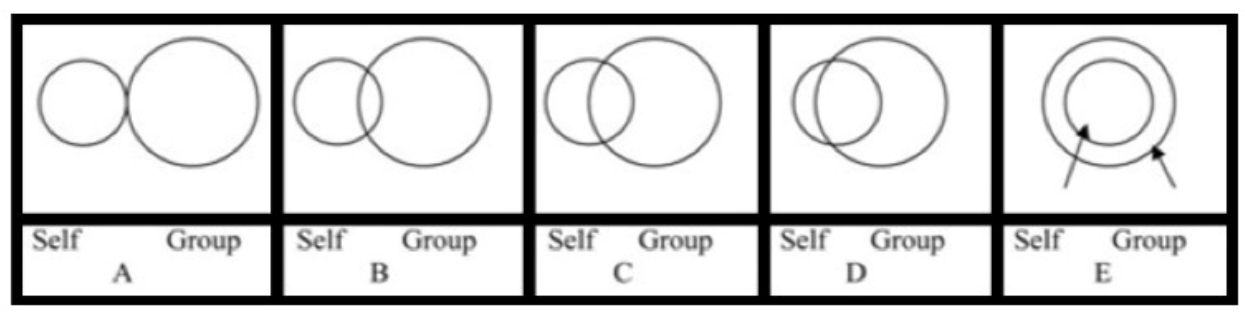

Figure 1. Identity Fusion Scale 
i.e. those who declared that their self-concept is placed completely in the group, as fused, the analysis of the results from groups $\mathrm{D}$ and $\mathrm{E}$ showed important similarities between people from the two groups in terms of group identification intensity. Following the method used in previous studies on identity fusion (Seyle, 2007), an analysis of variance (ANOVA) with a dependent variable of group identification and identity fusion as a continuous variable (on a 5-level Likert scale) was carried out. This analysis $(\mathrm{N}=872$, including participants from all four studies), showed significant differences in levels of identity fusion. ANOVA analysis showed the significance of differences with $\mathrm{F}$ (4.867) = $39.192, \mathrm{p}<.001$. According to Tukey's post hoc test, identification in the $\mathrm{E}$ group is significantly higher than in $\mathrm{A}$ to $\mathrm{C}$ groups ( $\mathrm{p}<$ .05 ) but it is not different from the results of the $\mathrm{D}$ group (see Figure 2).
In all four studies identity fusion and group identification were correlated $(\mathrm{r}=.391, \mathrm{p}<$ .001 in Study $1 ; \mathrm{r}=.398, \mathrm{p}<.001$ in Study 2; $\mathrm{r}=.415, \mathrm{p}<.001$ in Study 3 and $\mathrm{r}=.264, \mathrm{p}<$ .001 in Study 4) as were identity fusion and perceived prototypicality $(\mathrm{r}=.430, \mathrm{p}<.001$; $\mathrm{r}=.482, \mathrm{p}<.001 ; \mathrm{r}=.281, \mathrm{p}<.001 ; \mathrm{r}=.188 ; \mathrm{p}$ $<.01$, respectively).

\section{STUDY 1}

The goal of Study 1 was to explore, in a Central European context, if a previouslydemonstrated relationship between fusion and radicalization (Swann et al., 2009) could be replicated. The study was carried out over the Internet. In order not to concentrate on psychology students (see Henrich et al., 2010), the invitation to participate was placed on a number of Internet forums, as well as in local and Poland-wide social and informa-

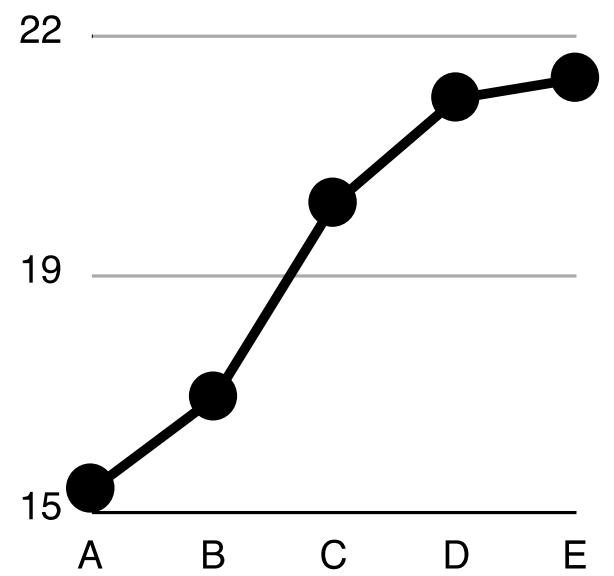

Figure 2. Group identification for each of the levels for Identity Fusion Scale 
tion network services. In the first study, I explored whether fused Poles were more willing to exhibit devotion to the group, and then I examined the relationship between fusion and group identification (which previously turned out to be significant but moderately strong) and a perceived prototypicality (which previously turned out not to be significant).

\section{Method and Participants}

Participants: 367 people took part in Study 1 (243 men, 112 women, 12 did not state their sex). Average age was 33.4 (11 participants did not state their age, $\mathrm{SD}=12.3$ ).

\section{Measures}

Participants completed a set of questionnaires with the following measures: a) Identity fusion was measured with a scale presented in Figure 1 and described above; b) as a measure of group identification, as with previous studies (Swann et al., 2010a; Swann et al., 2010b), the scale by Mael and Ashforth, 1992 was used $(\alpha=.85)$, specifically a six-item scale with statements such as "Successes of my country are my successes", "I am very interested in what citizens of other countries think about my country", etc.; c) prototypicality was measured using the question "To what extent do you consider yourself a typical Polish person?" on a 10-point Likert scale (with 1 meaning "not at all" and 10 "very much"); d) afterwards, participants answered questions describing their attitudes towards fighting for one's own group, dying for the group and defending the country. As with the procedure used by Swann et al. (2009), they completed these measures twice, once for them- selves $(\alpha=.68)$ and once for other group members (with the instruction to answer as other group members would answer; $\alpha=.80$ ). For willingness to fight for the group, participants rated their agreement with five items, e.g., "I would fight someone physically threatening another Pole", "I would fight someone insulting or making fun of Poland as a whole", on a 5-point Likert scale ranging from 1 (totally disagree) to 5 (totally agree). For willingness to die for the group, participants rated their agreement with the statement "I would sacrifice my life if it saved another group member's life", while for protecting the country, participants responded to the assertion "Should my country be attacked, I would actively try to take part in its defense and I would ignore the dangers".

\section{RESULTS}

Overall, $24.8 \%$ of participants chose option $\mathrm{E}$, that is a full overlap between selfand the country. These results are comparable to those obtained in the U.S. but the percentage of fused participants is lower than in Spain (e.g., Swann et al., 2009). However, the results distribution for the fusion scale was different from both the Spanish and American groups. While in those cases, options A or B were chosen by a minority of participants and scored notably lower than other answers, in the Polish sample, A and B were chosen often (see Figure 3). In the first study, B was the second most popular option, which indicates that a relatively large percentage of Poles does not see many intersections between their self-concept and their country.

Building on the method used by Swann et al. in one of their studies (2009), a difference score was created: perception of the self's 
Study 1

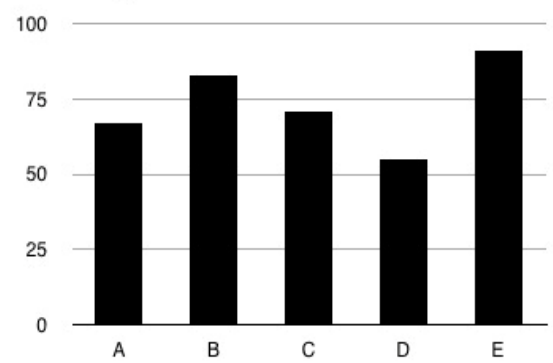

Study 3

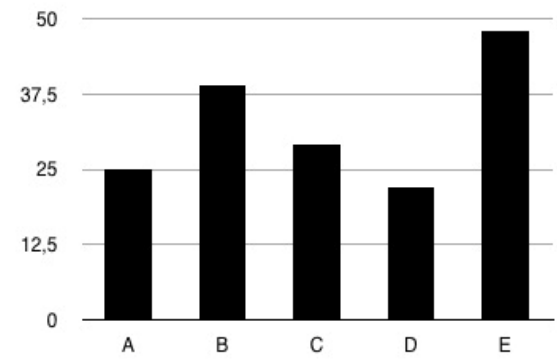

Study 2

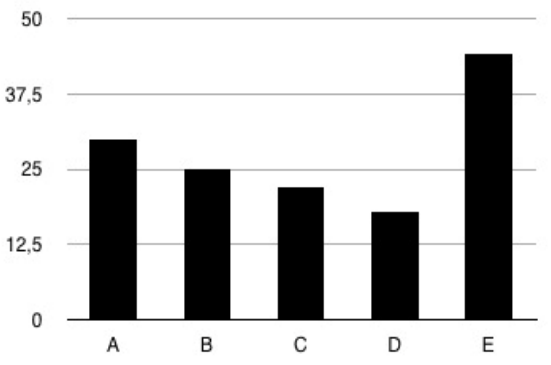

Study 4

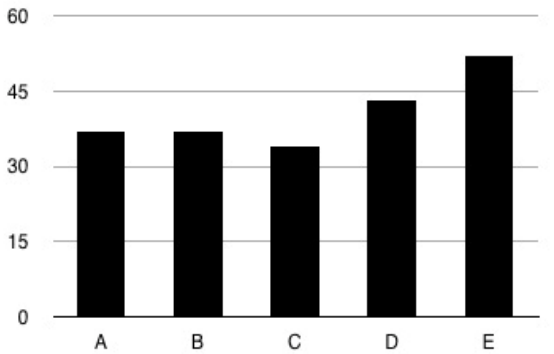

Figure 3. Distribution of scores on the fusion measure ( $\mathrm{X}$ axis identity fusion; $\mathrm{Y}$ axis frequencies)

willingness to fight for the group minus perception of other group member's willingness to fight for the group. A positive score indicates that participants thought they would be more willing to fight for the group than others, whereas a negative score indicates that they thought others would do more for the group. The same method was used for counting the difference score for the willingness to sacrifice oneself for the group and for the country's protection.

In order to determine if fusion is a significant predictor of extremism, three regression analyses were carried out using the enter method. The predictors were: fusion, identification and the interaction of fusion * identification. Age and sex were not included in the regression analyses because their effects were not significant (see Table 1).

As in the previous studies (Swann et al., 2009), fusion turned out to be a significant predictor of the willingness to fight for one's own group, self-sacrifice for the group, and the willingness to protect the country. For the willingness to fight for the group, some main effects of fusion emerged, such as that the difference score for fused participants (compared to nonfused participants) was less negative (Levene's F test of homogeneity of variance was significant, thusly: $\mathrm{t}(328)=4.37 ; \mathrm{p}<.001(\mathrm{M}=-.33$ vs. -2.95 , respectively). Fused persons were also more willing to sacrifice their lives for the group: $\mathrm{t}(365)=3.71 ; \mathrm{p}<.001(\mathrm{M}=.25$ vs. -.36 , re- 
Table 1. Enter regression analyses for fighting and dying for the group and for defending the country $(n=367)$

\begin{tabular}{|l|c|c|c|c|c|c|}
\hline & \multicolumn{2}{|c|}{ Fighting } & \multicolumn{2}{c|}{ Dying } & \multicolumn{2}{c|}{ Defending } \\
\hline Predictors & $\beta$ & $\mathrm{t}$ & $\beta$ & $\mathrm{t}$ & $\beta$ & $\mathrm{t}$ \\
\hline Fusion & .195 & $3.602 * * *$ & .145 & $2.704^{* *}$ & .202 & $3.821^{* * *}$ \\
\hline Identification & .082 & 1.517 & .161 & $3.015^{* *}$ & .174 & $3.300^{* * *}$ \\
\hline Fusion $\mathrm{x}$ Identification & -.012 & -.241 & -.090 & $-1.777^{\wedge}$ & -.062 & -1.229 \\
\hline
\end{tabular}

Note: ${ }^{\wedge} \mathrm{p}=.077, * \mathrm{p}<.05, * * \mathrm{p}<.01, * * * \mathrm{p}<.001$

adjusted R Square $=.047$ for fighting; .062 for dying, and .089 for defending the country

spectively). They also expressed greater willingness to protect the country no matter the price, with $\mathrm{t}(365)=5.00 ; \mathrm{p}<.001(\mathrm{M}=.39 \mathrm{vs}$. -.43 , respectively). Group identification measured with the Mael and Ashfort scale (1992) turned out to be a significant predictor of pro-group attitudes in two cases out of three.

Study 1 confirmed a relationship between identity fusion and pro-group attitudes. Nevertheless, in Study 2 another measure related to group defense was used, namely passive nationalism. Moreover, in this study the relationship between identity fusion and self-certainty was examined. This allows us to answer the question if indeed fused persons present more confidence about their traits and characteristics as a result of an overlap between personal and group selfconstruals.

\section{STUDY2}

Study 2 was carried out on the Internet. The first goal was to explore whether fusion is a significant predictor of passive nationalism, i.e., of the feeling that one's own group is an example for others and that it is the best possible group. The second goal was to examine the relationship between fusion and self-concept clarity. If the group fusion is a result of personal self and social identity overlap, it can be assumed that people displaying it should also display a greater self-concept clarity, as they know exactly who they are and they do not have conflicting dimensions between social and personal self.

\section{Method and Participants}

Participants: 139 people took part in this study (94 men, 44 women, 1 person did not state their sex). Average age was 40.5 (SD = 15.2).

\section{Measures}

As measures of a) identity fusion, b) group identification $(\alpha=.85)$, and c) perceived group prototypicality, the same scales as in Study 1 were used.

For d) Radkiewicz's passive nationalism scale was used (2005). The scale consists of four statements (e.g., "The world would be a better place if people in other countries were more like Poles"; $\alpha=.71$ ). The participants state their view on a scale from 1 ("I completely disagree") to 5 ("I completely agree"). Finally, e) participants were asked to answer 10 items from the self-concept clarity scale that measures certainty about one's characteristics, goals and traits $(\alpha=.78)$ (Campbell 
et al., 1996; for an example of the application of a Polish version of this scale, see: Błażek, Besta, 2012).

\section{RESULTS}

In this Study $31.7 \%$ of participants chose option E. Once again the specific character of the Polish sample emerged, namely that the second most common chosen option was $\mathrm{A}$, that is seeing no connection between the self and the group (see Figure 3).

In order to test whether fusion is a significant predictor of passive nationalism and selfconcept clarity, while controlling for group identification, regression analysis with the enter method was conducted. The predictors were: fusion, identification and interaction between fusion * identification (see Table 2).

The only significant predictor of passive nationalism turned out to be identity fusion. Fused people displayed greater devotion to country and perceived it as an example for others $(\mathrm{M}=10.84)$ to greater extent than nonfused people $(M=7.96), t(137)=4.55$; $p<.001$. The only significant predictor of self-concept clarity turned out to be the interaction of fusion and identification. The tendency of nonfused participants to score differently on the self-concept clarity scale depended on the level of identification. When comparing the results of people with low $\left(1^{\text {st }}\right.$ quartile) and high ( $4^{\text {th }}$ quartile) identification levels, it turned out that people who are nonfused but score high on identification with the country scale display lower selfconcept clarity $(\mathrm{M}=3.4)$ compared to both people with high identification level and high fusion $(\mathrm{M}=3.98), \mathrm{t}(33)=2.75 ; \mathrm{p}<.01$ and to nonfused people with low level of identification with the country $(\mathrm{M}=4.0), \mathrm{t}(32)=2.17$; $\mathrm{p}<.05$.

In short, significantly lower self-concept clarity among nonfused people with strong group identification (i.e., those who do not relate their personal self with group but at the same time strongly identify with their country) indicates a certain conflict of identities among those people, as well as less certainty about their own personal characteristics.

As in Study 1 identity fusion was related to the willingness to fight and die for a group and in Study 2 to passive nationalism, so Study 3 examined if this pattern of pro-group behaviors would also be confirmed by answers to the moral trolley dilemma. Additionally, the relationship between identity fusion and locus of control was investigated.

Table 2. Enter regression analyses for passive nationalism and self-concept clarity $(\mathrm{n}=$ 139)

\begin{tabular}{|l|c|c|c|c|}
\hline & \multicolumn{2}{|c|}{ Passive Nationalism } & \multicolumn{2}{c|}{ Self-Concept Clarity } \\
\hline Predictors & $\beta$ & $\mathrm{t}$ & $\beta$ & $\mathrm{t}$ \\
\hline Fusion & .311 & $3.659^{* * *}$ & .100 & 1.112 \\
\hline Identification & .140 & $1.640^{\wedge}$ & -.152 & $-1.687^{\wedge \wedge}$ \\
\hline Fusion $\mathrm{x}$ Identification & .037 & .467 & .181 & $2.154^{*}$ \\
\hline
\end{tabular}

Note: ${ }^{\wedge} \mathrm{p}=.10,{ }^{\wedge \wedge} \mathrm{p}=.094, * \mathrm{p}<.05, * * \mathrm{p}<.01, * * * \mathrm{p}<.001$

adjusted $\mathrm{R}$ Square $=.131$ for passive nationalism and .030 for self-concept clarity 


\section{STUDY 3}

Study 3 was carried out on the Internet. In order to prevent focusing on psychology students the invitation was placed on a number of Internet forums, as well as local and Poland-wide social and information network services. The first goal of the study was to test whether fused Polish people are willing to self-sacrifice for in-group members to the same extent as representatives of other nations. To test the willingness to self-sacrifice, some researchers have used a modified trolley problem (see Swann et al., 2010a), which was used in Study 3 as well. The second goal of Study 3 was to test the relationship between fusion and sense of control over one's life.

\section{Method and Participants}

Participants: 163 people participated in the study (126 men and 37 women). Average age was $32(\mathrm{SD}=13.2)$.

\section{Measures}

As in previous studies, participants completed a) the identity fusion scale (Figure 1) and $b$ ) the group identification scale (Mael, Ashforth, 1992; $\alpha=.78$ ). In order to test c) whether a positive relationship between fusion and sense of prototypicality depends on the form of question asked, different questions from Studies 1 and 2 were used in Studies 3 and 4, namely: "To what extent are you similar to an average Polish man/Polish woman?" Participants also responded d) to the question measuring locus of control ("To what extent do you agree that you have no control over your life?"). The answers were set on a 10-point Likert scale from 1 (completely disagree) to 10 (completely agree). After answering the questionnaire items, participants were presented the trolley problem:

You are on a trolley that is running down its track in the mountains. Unfortunately along the track five tourists from a different part of Poland (vs. from China) are stand taking photos. They did not hear the trolley coming and now they have nowhere to go since the track runs in a ravine. Fortunately, right in front of them the rails fork. If you go ahead the tourists will definitely die. The brake does not work but there is a switch that allows you to change the trajectory of the trolley at the fork. Unfortunately, at the end of this sidetrack is a stone wall. If you choose this track the probability that you die is $99 \%$. Would you change the trajectory of the trolley?

Participants were randomly assigned to a group where potential victims in trolley problem were tourists from another part of Poland (in-group members) or tourists from China (out-group members). Only after the questions did the participants declare their age and sex.

\section{RESULTS}

As to the identity fusion scale, $29.4 \%$ of participants chose option E. No significant differences emerged in the perceived sense of control between fused and nonfused people. It is possible that one item to which participants responded was not measured reliably enough.

Fusion and trolley problem: The distribution of responses turned out to be consistent with our predictions: a higher percentage of fused people declared the will- 
ingness to self- sacrifice for in-group members than nonfused people. However, when binary logistic regressions were used separately for in-group and out-group members (with predictors: fusion [dummy-coded], group identification [centered], and the interaction fusion * identification), there were no statistically significant main or interactive effects, neither for in-group (58.3\% among fused people and $42.6 \%$ among nonfused) nor for out-group members (44.1\% among fused people and $26.1 \%$ among nonfused). Therefore there is no support for rejecting the hypothesis of independence of obtained results.

It is possible that leaving this $1 \%$ chance of survival when introducing themoral dilemma changes the study conditions. It might facilitate theoccurrence of too many false positives, i.e., people who are not fully convinced whether theywould sacrifice their lives in such an extreme situation might still mark their answer as "yes" because of a minimal chance of survival there (even ifit is only $1 \%$ ).

In order to make the difference more distinct between people who are willing to sacrifice their lives, in Study 4 the dilemma was to declare one's willingness to let five tourists die (in-group vs. out-group) or to sacrifice oneself. In a similar dilemma, Spanish respondents who were closely fused with country chose own death in $75 \%$ of cases (in comparison with $25 \%$ among nonfused people).

\section{STUDY 4}

\section{Method and Participants}

Participants: 203 people participated in the study (141 men and 62 women). Average age was $34.2(\mathrm{SD}=12.9)$.

\section{Measures}

Study 4 had a similar schema to Study 3 ( $\alpha$ for the identification scale was .81). The only differences were adding a locus of control scale and a social desirability scale. Both scales are tested and validated in the Poland Delta Questionnaire (Drwal, 1995). This questionnaire consists of 24 "true-false" items, out of which 14 constitute the locus of control scale (LOC, e.g., "Very often I feel I have no influence over what happens to me", "Getting a good job mostly depends on a lucky coincidence", etc.; $\alpha=.79$ ) and 10 items measure social desirability $(\alpha=.46)$. This measure showed weaker internal consistency than in previous studies; as such, we recommend caution when interpreting the results concerning social desirability. In Study 4 we also changed the trolley problem. The end of the new trolley problem was as follows:

Unfortunately, at the end of this sidetrack there is a stone wall. If you choose this track you will die. Would you change the trajectory of the trolley?

\section{RESULTS}

$25.6 \%$ of participants chose option $\mathrm{E}$ on the fusion scale. Differences in locus of control between fused and nonfused people emerged. Nonfused people displayed a greater external locus of control than fused people (fusion $\mathrm{M}=3.58$ vs. without 4.45 ); $\mathrm{p}<.05$.

Fusion and trolley problem: Distribution of responses turned out to be consistent with our predictions: a higher percentage of fused people declared willingness to sacrifice themselves for in-group members in comparison with nonfused people. We used bi- 
nary logistic regressions to examine the impact of fusion (dummy coded), group identification (centered), and the interaction fusion $*$ identification on the willingness to sacrifice oneself, separately for in-group and out-group members. As could be seen in Table 3, for the in-group members a main effect of fusion emerged, and $40.8 \%$ of fused people chose self-sacrifice (vs. $20 \%$ nonfused) $\chi^{2}(1,109)=5.67 ; p<.05$. Group identification had no main or interactive effects. In a group with a dilemma of self-sacrificing for the out-group members, there were no significant effects. Thus, it has been confirmed that fused people are more willing to sacrifice their lives for their fellow group members.

Fusion as a predictor of external locus of control and social desirability. In order to examine if fusion is a significant predictor of locus of control and social desirability, two regression analyses were carried out, using the enter method. The predictors were: fusion, identification, interaction of fusion and identification and sex (see Table 4). Fusion turned out to be the only significant predictor (on the level of statistical tendency) of the internal locus of control. Nonfused people displayed greater external locus of control than fused people (fused $\mathrm{M}=3.58$ vs. nonfused 4.45); $\mathrm{p}<.05$. This is consistent with the suggestions that fusion allows people to identify with the group while keeping a strong personal identity (Swann et al., 2010a) and without the need for depersonalization and turning to the group for guidance on how to behave and what to think.

Our concerns regarding the relationship between fusion and social approval were not confirmed; it is not the fused people who

Table 3. Summary of binary logistic regression in Study 4 for predictors of self-sacrifice for in-group members in the trolley problem $(n=203)$

\begin{tabular}{|l|c|c|c|}
\hline Predictors & B & Wald & OR \\
\hline Fusion & .480 & $4.49^{*}$ & 1.62 \\
\hline Identification & .045 & .683 & 1.05 \\
\hline Fusion $x$ Identification & -.062 & 1.31 & .94 \\
\hline
\end{tabular}

Note: $* \mathrm{p}<.05$

Table 4. Enter regression analyses for external locus of control and social desirability $(\mathrm{n}=203)$

\begin{tabular}{|l|c|c|c|c|}
\hline & \multicolumn{2}{|c|}{ External locus of control } & \multicolumn{2}{c|}{ Social desirability } \\
\hline Predictors & $\beta$ & $\mathrm{t}$ & $\beta$ & $\mathrm{t}$ \\
\hline Sex & .002 & .027 & .143 & $2.040^{*}$ \\
\hline Fusion & -.138 & $-1.89^{\wedge}$ & .020 & .276 \\
\hline Identification & .002 & .024 & .159 & $2.170^{*}$ \\
\hline Fusion x Identification & -.035 & -.486 & .026 & .372 \\
\hline
\end{tabular}

Note: ${ }^{\wedge} \mathrm{p}=.06, * \mathrm{p}<.05$

adjusted R Square $=.0001$ for external locus of control and .023 for s social desirability 
display greater sensitivity to others' opinions. Two significant predictors were the group identification and sex (with men $\mathrm{M}=$ 1.38 scoring lower than women $\mathrm{M}=1.76$ on the social desirability scale). People who display stronger relationship with the group also show greater need for approval. This result confirms, at the same time, the thesis of relative independence of fusion and identification constructs (or at least measures used in the study), despite the relationship between them.

\section{DISCUSSION}

The presented research replicates previous findings regarding the construct of identity fusion in different cultural contexts. Moreover, the studies explore the relationship between fusion and a set of new variables. The series of studies confirmed that fused people in comparison with nonfused ones show a greater willingness to fight for their group, to defend the group and to selfsacrifice for in-group members. This confirms the previous study on the identity fusion theory (Swann et al., 2012). Moreover, results of previous studies on the trolley problem (Swann et al., 2010) were also confirmed. Persons fused with a group were more willing to sacrifice their lives for their fellow group members. Similar result was obtained with a scale of passive nationalism. This measure was introduced to replicate the relationship between fusion and pro-group attitudes with yet another measure of group adherence. It turned out that identity fusion was a stronger predictor of passive nationalism than group identification. Summarizing the results on the relationship between fusion and radical pro-group attitudes, the state of identify fusion could be seen as a state that predis- poses people to act on behalf of the group, and engage themselves in radical behaviors in order to save in-group members.

As noted above, the previously demonstrated relationship between fusion and radical pro-social attitudes (which were operationalized in various ways) has been confirmed. However, it should be stressed that when it comes to some dependent variables, the relationship between fusion and radical attitudes was not visibly stronger than the relationship between group identification and those attitudes. Furthermore, the differences in declared self-sacrifice for ingroup members in the trolley problem between fused and nonfused persons were less clear than in the study by Swann et al. (2010a).

As for the specific cultural context of the relationship of Poles with their country, the tendency to justify the existing social system that is visible in many nations is low in Poland, where the system itself is seen as unjust and harmful (Wojciszke, 2004). The results of the current studies indirectly confirm this assumption. The mean results of the pictorial fusion scale show that significant percent of Polish participants do not feel a strong connection with their country. For example, in Spain (Swann et al., 2009) answers A and B were the ones chosen the least often. In Poland on the other hand, in three studies, the second most often chosen option was B (seeing very little overlap between me and the country) or A (seeing no connection at all).

When compering current results with results from previous studies from Spain and the USA, differences emerged. For Polish samples, the assumption that fused people perceive themselves as unique among group members (Swann et al., 2009, p. 1001) was 
not supported. Fusion was related to perceiving oneself as a typical member of the group. This result is consistent with the theory of social identity. According to that theory, when a person identifies with the group it leads to perceiving oneself as the prototypical member of the group and as interchangeable with other group members. Therefore, the first explanation for the relationship between fusion and prototypicality could be that the concepts of group identification and fusion with group are not as independent as Swann et al. (2009) claim. Identity fusion, like strong identification, could sometimes be related to the perceived group prototypicality. The second explanation for this relationship could be the specific character of the Polish sample. Here, people who perceived their self as strongly fused with the group at the same time believe that typical Poles think in a similar way about their relationship with the group. Other dependencies support the specific character of the Polish sample. In contrast to the previous studies, a large proportion of participants chose options A and B (meaning lack of common feeling between self and group or only a very small overlap). Therefore, people who feel loosely tied to the current social order in their country could be responsible for the revealed relationship between fusion and typicality. While not identifying with the group, they claimed to be radically atypical representatives of the group. In comparison, moderate responses of fused people turned out to suggest their higher prototypicality. In order to explain these interesting cultural differences in more detail, it is necessary to conduct more studies that have a variety of measures of prototypicality.

As for the tested relationships that extended the results of the earlier research, there were some interesting results. For example, no relationship has been shown between fusion and social approval. This may suggest that pro-social responses of the fused people were not related to their higher need for providing socially desirable answers. At the same time, people who display stronger group identification also show stronger need for approval. Differences in the links to social desirability might confirm the postulate of relative independence of identity fusion and group identification constructs. Similarly, our analysis of the relationship between fusion and locus of control is consistent with suggestions made by Swann et al. (2010a) on the lack of depersonalization for identity fusion and keeping the individual personal identity as the determinant of attitudes, in spite of uniting with the group's values and opinions. Additionally, interaction between fusion and identification was a significant predictor of self-concept clarity. Fused people, regardless of the identification level, display a constant self-concept clarity level. At the same time people with strong group identification but whose personal identities do not overlap with group ones display the lowest self-concept clarity level. This is yet another indirect argument that fusion and identification are related, but independent constructs.

Received April 2, 2013

\section{REFERENCES}

ARON, A., ARON, E.N., SMOLLAN, D., 1992, Inclusion of Other in the Self Scale and the structure of interpersonal closeness. Journal of Personality and Social Psychology, 63, 596-612, doi:10.1037/0022-3514.63.4.596

BŁAŻEK, M., BESTA, T., 2012, Self-concept clarity and religious orientations: Prediction of purpose in life and self-esteem. Journal of Religion 
and Health, 51, 3, 947-960, doi:10.1007/s10943010-9407-y

CAMPBELL, J.D., TRAPNELL, P.D., HEINE, S.J., KATZ, I.M., LAVALLEE, L.F., LEHMAN, D.R., 1996, Self-concept clarity: Measurement, personality correlates, and cultural boundaries. Journal of Personality and Social Psychology, 70, 1, 141-156, doi:10.1037/0022-3514.70.1.141

DOLINSKI, D., 1996, The mystery of the Polish soul. BW Johnson's effect à rebours. European Journal of Social Psychology, 26, 6, 1001-1005.

DRWAL, R.A., 1995, Adaptacja kwestionariuszy osobowości. Warszawa: PWN.

GÓMEZ, A., BROOKS, M.L., BUHRMESTER, M.D., VÁZQUEZ, A., JETTEN, J., SWANN, W.B., Jr., 2011, On the nature of identity fusion: Insights into the construct and a new measure. Journal of Personality and Social Psychology, 100, 5, 918 933, doi:10.1037/a0022642

HENRICH, J., HEINE, S.J., NORENZAYAN, A., 2010, The weirdest people in the world? Behavioral and Brain Sciences, 33, 2-3, 61-83, doi: 10.1017/S0140525X0999152X

JOST, J.T., BANAJI, M.R., NOSEK, B.A., 2004 A decade of system justification theory: Accumulated evidence of conscious and unconscious bolstering of the status quo. Political Psychology, 25, 6, 881-919, doi: 10.1111/j.1467-9221.2004 $.00402 . \mathrm{x}$

MAEL, F., ASHFORTH, B.E., 1992, Alumni and their alma mater: A partial test of the reformulated model of organizational identification. Journal of organizational Behavior, 13, 2, 103-123, doi:10.1177/0146167294205005

SEYLE, D.C., 2007, Identity fusion and the psychology of political extremism. Unpublished dissertation for the degree of Doctor of Philosophy. The University of Texas at Austin. Retrieved from http:/ /repositories.lib.utexas.edu/handle/2152/3027.

SHERIF, M., HARVEY, O.J., WHITE, B.J., HOOD, W.R., SHERIF, C.W., 1961, Intergroup conflict and cooperation: The Robbers Cave experiment. Norman, Okla.: University Book Exchange.
SWANN, W.B., Jr., GÓMEZ, A., DOVIDIO, J.F., HART, S., JETTEN, J., 2010a, Dying and killing for one's group: Identity fusion moderates responses to intergroup versions of the trolley problem. Psychological Science: A Journal of the American Psychological Society, 21, 8, 1176-1183, doi:10.1177/0956797610376656

SWANN, W.B., Jr., GÓMEZ, A., HUICI, C., MORALES, J.F., HIXON, J.G., 2010b, Identity fusion and self-sacrifice: Arousal as a catalyst of progroup fighting, dying, and helping behavior. Journal of Personality and Social Psychology, 99, 5, 824-841, doi:10.1037/a0020014

SWANN, W.B., Jr., GÓMEZ, A., SEYLE, D.C., MORALES, J.F., HUICI, C., 2009, Identity fusion: The interplay of personal and social identities in extreme group behavior. Journal of Personality and Social Psychology, 96, 5, 995-1011, doi:10.1037/ a0013668

SWANN, W.B., Jr., JETTEN, J., GÓMEZ, A., WHITEHOUSE, H., BASTIAN, B., 2012, When group membership gets personal: A theory of identity fusion. Psychological Review, 119, 3, 441-456, doi: $10.1037 / \mathrm{a} 0028589$

SWANN, W.B., Jr., STEIN-SEROUSSI, A., GIESLER, R.B., 1992, Why people self-verify. Journal of Personality and Social Psychology, 62, 3, 392-401, doi: 10.1037/0022-3514.62.3.392

TAJFEL, H., TURNER, J.C., 1979, An integrative theory of intergroup conflict. In: W.G. Austin, S. Worchel (Eds.), The Social Psychology of Intergroup Relations. Monterey, CA: BrooksCole.

TURNER, J.C., HOGG, M.A., OAKES, P.J., REICHER, S.D., WETHERELL, M.S., 1987, Rediscovering the social group: A self-categorization theory. Basil Blackwell.

WOJCISZKE, B., 2006, Looking down at the rich? ACADEMIA, 4, 12, 8-11. Retrieved from http:/ /www.academia.pan.p1/pdfen/richness_0811 wojciszke.pdf

WOJCISZKE, B., 2004, The negative social world: The Polish culture of complaining. International Journal of Sociology, 34, 4, 38-59. 


\section{PRIENIK OSOBNEJ A SKUPINOVEJ IDENTITYA JEHO VZŤAH K RADIKÁLNYM PRO-SKUPINOVÝM POSTOJOM: ÚDAJE ZO STREDOEURÓPSKEHO KULTÚRNEHO RÁMCA}

\section{T. B e s t a}

Súhrn: Predchádzajúci výskum ukázal, že vernost' skupine, ktorá sa manifestuje vo fúzii osobnej a spoločenskej identity, súvisí s radikálnymi pro-skupinovými postojomi a že tento vzt'ah je silnejší pre fúziu identity než pre identifikáciu so skupinou. Séria štyroch štúdií (n=872) skúmala, či v rôznych kultúrnych podmienkach (t.j. v strednej Európe) sa fúzia identity spája s postojmi na obranu vlastnej skupiny a či vplýva na deklarovanú tendenciu sebaobetovania. Okrem toho, aby sme rozšírili doterajšie výsledky, prezentovaná štúdia testovala, či sa fúzia spája so zmyslom pre kontrolu, spoločenským uznaním a jasným sebapoňatím. Výsledky naznačujú, že fúzia identity (meraná na obrázkovej škále) sa spája s radikálnym správaním operacionalizovaným rôznymi spôsobmi a s pocitom sebaistoty. 